cesses - the industries represented by Bush's companions in Japan the other week.

Bush is also right to declare, as he did last week, that the United States needs better public education and general health insurance of some kind if it is to make the best use of its people, and to give them what they want. Nobody will quarrel about the medicine prescribed, but there will be endless argument about the means of its delivery. In any case, as the rest of the world knows, these are areas in which publicly directed social engineering is as tricky and difficult as attempts by civil servants to second-guess the ideal development of industry.

So must uncertainty persist? Not necessarily. For one thing. Bush reaffirmed last week the Administration's commitment to research. That is splendid, and as it should be; let us hope that the Congress gives Bush what he asks for (see page 486). By good luck, Bush also has the world's most flexible economy to sustain him, a splendid record of even recent innovation in technical fields that matter (or will matter) a great deal and an ebullient people. The short-term battle against recession may take longer than anybody is yet telling, but the long-term war is winnable, provided that a few conditions can be met. First, the federal deficit must be made to melt away, even if that means cutting back on the Strategic Defense Initiative, the space station Freedom and even the Superconducting Super Collider. Second, public education deserves even more attention than Bush promised in his address three years ago, when he seemed bent on becoming the "education president". Why has so little happened since the need was first identified and clearly articulated a decade ago?

Finally, the United States needs to play a trick on itself, with the help of Bush or his successor. With France, it enjoys a constitution in which personal liberty is eloquently enshrined. But the lower parts of the social heap have recently become uncomfortably conspicuous for everybody. Social problems, from drugs to homicide, undermine not merely peace of mind but the capacity of the US to function as the unitary state it used to be. Before President Lyndon Johnson was submerged by Vietnam, he lifted people's spirits with the slogan of "the Great Society". Nobody would expect Republican Bush to sing the same tune, but the problems are the same and there needs to be a tune. Will Bush or anybody find one before November? Presumably that is what the election is about. $\square$

\section{Election fever}

There seem to be elections everywhere, but the British version promises little for science.

EVERYWHERE, there seems an election around the corner. France, for example, will hold municipal elections in May, followed by parliamentary elections next year (if not sooner). The United States, whose predictable electoral cycle is thereby also protracted, is already in the thick of a campaign concluding only in November. Britain, where the timing of elections is in the gift of the prime minister and his party, must hold an election before mid-July, but will probably be at the polls in early April. The incumbent governments in the United States and France will be banging the drum for research: France's encouragement of research in the past decade may be the Mitterrand governments' only lasting achievement, while President George Bush last week pinned his faith in a restoration of US competitiveness on federal research spending (and tax incentives). By contrast, but as expected, little has been heard as yet in Britain.

That is a shame, reflecting the universal embarrassment of British politicians about an issue they do not understand. Gone are the days when the then Mr Harold (later Lord) Wilson was elected prime minister in 1964 on a promise of prosperity by "white-hot technology"; his Labour successors offer instead a sensible pattern of what they call training - and have been galled to find that the government party has stolen their prospectus (for which there is little yet to show). The politicians' difficulty is not with the Wilson doctrine, but their puzzlement that it seems not to apply in Britain. The explanation is not that researchers are layabouts and indifferent to national needs, even if that hypothesis of Mrs Margaret Thatcher's has shaped British policy on research for a decade. The fault lies instead with British industry and the economic climate in which it seeks survival. Why else has not British industry been more daring on the strength of know-how garnered from elsewhere, as Japanese companies are often wrongly said to have prospered (see page 493)? It is not that British research's needs of its paymasters are obscure. This journal's Manifesto for British Science (Nature 353, $105 ; 1991)$ has spelled out many of them.

The academic sector exists to recruit able people and to educate them in research, but its practitioners are grossly underpaid, as are the students they recruit. That state of affairs compromises Britain's future, not only because educated and skilled people go elsewhere, but because recruitment lags. The link between the academic sector and industrial innovation is something else again. With the exception of those in the pharmaceutical industry, British companies have slipped into skimping on longterm research and development, often quoting investors' short-term demands as their excuse. So governments and their opponents are hunting for means of presenting industry with innovative technology, neatly bundled in tasteful gift-wrapping. That is one reading of President Bush's National Technology Initiative, given an airing last week. The British equivalent may well be the content of a paper prepared for the Engineering Council by Dr John Fairclough, previously chief scientific adviser at the Cabinet Office, who advocates sector-based research institutes along the lines of Germany's Fraunhofer institutes. Before the government seizes on this to fill out its thin election manifesto, it should reflect that its predecessors stopped supporting industrial research associations as recently as the 1970s and that Japanese success in recent decades hangs on the close integration of research and development within the structure of a company. 